\title{
Evaluation of the in vitro and in vivo inhibitory effect of thymoquinone on piroplasm parasites
}

\author{
Shimaa Abd El-Salam El-Sayed ${ }^{1,2}$, Mohamed Abdo Rizk ${ }^{1,3}$, Naoaki Yokoyama ${ }^{1}$ and Ikuo Igarashi ${ }^{*}$
}

\begin{abstract}
Background: Developing new antibabesial drugs with a low toxic effect to the animal and with no resistance from Babesia parasites is in urgent demand. In this concern, the antimalarial, anticancer and antioxidant effect of thymoquinone (TQ), a phytochemical compound found in the plant Nigella sativa, has been reported. Therefore, in the present study, the antibabesial effect of this compound was evaluated on the growth of piroplasm parasites.

Results: Significant inhibition $(P<0.05)$ of the in vitro growth of piroplasm parasites were observed after treatment by TQ with $I_{50}$ values of $35.41 \pm 3.60,7.35 \pm 0.17,0.28 \pm 0.016,74.05 \pm 4.55$ and $67.33 \pm 0.94 \mu \mathrm{M}$ for Babesia bovis, Babesia bigemina, Babesia divergens, Theileria equi and Babesia caballi, respectively. The in vitro inhibitory effect of TQ was significantly enhanced $(P<0.05)$ when used in combination with either diminazene aceturate on bovine Babesia and equine Babesia and Theileria cultures. In B. microti-infected mice, oral and intraperitoneal administrations of TQ showed significant $(P<0.05)$ inhibition of parasite growth at a dose of $70 \mathrm{mg} / \mathrm{kg}$ and $50 \mathrm{mg} / \mathrm{kg}$, respectively, compared to the control group.
\end{abstract}

Conclusions: The obtained results indicate that thymoquinone might be a promising medicinal compound for use in the treatment of animal piroplasmosis.

Keywords: Babesia, Theileria, Thymoquinone, In vitro, In vivo

\section{Background}

Piroplasmosis is a tick-borne disease of huge economic importance in the animal industry worldwide. The disease has zoonotic importance and is caused by hemoprotozoan parasites [1]. The main etiological agents of the disease in cattle are Babesia bovis and B. bigemina [1]. Moreover, Babesia divergens has a substantial impact on cattle health and productivity and has zoonotic importance [2]. In equines, the disease is caused by Theileria equi and B. caballi [3]. Generally speaking, babesiosis is typified in animals by high fever, hemolytic anemia and hemoglobinuria [1]. In fact, in recent years the inhibitory effects of many drugs such as epoxomicin, ciprofloxacin, thiostrepton and rifampicin, $[4,5]$ as well as pyronaridine tetraphosphate, luteolin, nimbolide,

\footnotetext{
* Correspondence: igarcpmi@obihiro.ac.jp

${ }^{1}$ National Research Center for Protozoan Diseases, Obihiro University of Agriculture and Veterinary Medicine, Inada-Cho, Obihiro, Hokkaido, Japan Full list of author information is available at the end of the article
}

gedunin, enoxacin and N-acetyl-L-cysteine [6-8] have been evaluated against Babesia and Theileria parasites. However, none are yet available for commercial use in the veterinary market. Diminazene aceturate (DA) is commonly used to treat animal piroplasmosis under field conditions. However, it does not achieve complete elimination of parasites from hosts. Consequently, a relapse of infection in treated animals occurs [9]. Moreover, toxic side effects to the host and resistance from Babesia parasites has developed from the currently available antibabesial drugs in the veterinary field, imidocarb dipropionate and DA, respectively [9]. Therefore, developing new drugs with a low toxic effect to the animal and with no resistance from the parasite is a great priority. In this regard, Nigella sativa (black cumin) is one of the most important medicinal plants, known for its antioxidant, anti-inflammatory, antibacterial, antiviral, antiparasitic, anticarcinogenic, antiallergic, antidysenteric and antiulcer effects [10, 11]. Additionally, the 
immunoregulatory and immunomodulatory effects of this plant have been proven [11]. The main component within $N$. sativa is thymoquinone (TQ) (30-48\%) [12]. Notably, the antimalarial efficacy of TQ has been proven in vitro and in vivo against the growth of Plasmodium berghei in mice [13]. Additionally, previous studies have proven the anticancer [14] and antioxidant [15] effects of TQ. Furthermore, this phytochemical compound can ameliorate the toxic effects of some conventional medicine such as cisplatin [16] and doxorubicin [17] on the kidney and heart, respectively. However, the antibabesial effect of TQ has not yet been evaluated. Therefore, in the present study, the potential of TQ against piroplasm parasites was evaluated.

\section{Methods}

\section{Parasites}

The Texas strain of $B$. bovis, $[5,6]$ the Argentina strain of $B$. bigemina, $[6,18]$ the German bovine strain of $B$. divergens [7, 8] and U.S. Department of Agriculture (USDA) strains of B. caballi [8] and T. equi $[3,6]$ were cultivated in purified bovine or equine red blood cells (RBCs) using a microaerophilic stationary-phase culture system $[6,18]$ and used for the in vitro experiment. The Munich strain of B. microti [4] was maintained by passage in the blood of BALB/c mice (CLEA, Tokyo, Japan) [19] and used in the in vivo study.

\section{Chemical reagents}

TQ (Sigma-Aldrich, Tokyo, Japan) was prepared as 100 $\mathrm{mM}$ stock solutions and stored at $-30{ }^{\circ} \mathrm{C}$ until use. Olive oil (Ajinomoto, Japan) was used for dissolving TQ. DA (Novartis, Tokyo, Japan) was used as a positive control drug. SYBR Green I (SGI) nucleic acid stain (Lonza, Rockland, USA; $10,000 \times$ ) was mixed with a lysis buffer [Tris (130 mM; pH 7.5), EDTA (10 mM), saponin $(0.016 \% ; \mathrm{W} / \mathrm{V})$ and TritonX-100 (1.6\%; V/V)] and used for the fluorescence assay.

\section{TQ evaluation against Babesia and Theileria parasites in vitro}

The inhibitory effects of TQ on piroplasma growth were evaluated using the Babesia fluorescence assay (BFA) previously described by Rizk et al. [6, 7]. Briefly, parasite-infected RBCs were cultivated in double 96-well plates (Nunc, Roskilde, Denmark) for 4 days using Medium 199 (for B. bovis, B. bigemina and T. equi) and RPMI 1640 medium (for B. divergens and B. caballi) (both from Sigma-Aldrich) alone or with the indicated concentrations: $0.25,0.5,1,5$ and $10 \mu \mathrm{M}$ for DA or 0.01 , $0.1,0.25,0.5,1,5,10,25,50,100,200,400$ and $800 \mu \mathrm{M}$ for TQ. Each drug concentration was loaded into each well in triplicate. On the fourth day of culture, $100 \mu \mathrm{l}$ of lysis buffer was mixed with $2 \times$ SGI and added to each well in the first 96-well plate for calculation the $\mathrm{IC}_{50}$ of TQ for each parasite. The second 96-well plate was used for evaluation of the parasites' viability after treatment with TQ, as formerly described by Rizk et al. [7, 8]. The emitted fluorescence signals were determined using a fluorescence plate reader (Fluoroskan Ascent, Thermo Electron Informatics, Philadelphia, PA, USA).

\section{In vitro drug combination test}

Different concentrations of TQ with the commonly used antibabesial drug, DA were applied as previously described $[5,8,19,20]$ with some modifications. Combinations of TQ and DA were examined against the in vitro culture of B. bovis, B. bigemina, B. caballi and $T$. equi. Untreated cultures and cultures treated with only DA $\mathrm{IC}_{50}$ for Babesia and Theileria parasites were used as controls. The fluorescence values were determined as described earlier [8] for the fluorescence assay.

\section{Chemotherapeutic evaluation of TQ in mice}

The inhibitory effect of TQ against B. microti in a mouse model was performed in the present study using a fluorescence assay [21]. Collectively, 55 female 8-week-old $\mathrm{BALB} / \mathrm{c}$ mice were used in the in vivo study. Thirty mice were used for evaluating the inhibitory effect of TQ on B. microti when administrated via the oral route, while another 25 mice were used for evaluating the antibabesial effect of intraperitoneal (IP) injection of TQ.

For the 30 mice that received TQ via the oral route, the mice were divided equally into six groups. Mice in the first five groups were intraperitoneally inoculated with $1 \times 10^{7}$ B. microti-infected RBCs, while mice in the sixth group remained without infection and were used as a blank control. In the first and second groups, TQ was orally administered with non-toxic doses at a dose rate of 100 and $70 \mathrm{mg} / \mathrm{kg}$, respectively [22]. Combination therapy consisting of $50 \mathrm{mg} / \mathrm{kg}$ TQ and $10 \mathrm{mg} / \mathrm{kg}$ DA was administrated in the same inoculation period to the mice in the third group by oral and subcutaneous routes, respectively. DA at a dosage of $25 \mathrm{mg} / \mathrm{kg}$ was subcutaneously administrated to the fourth experimental group. TQ and DA were dissolved in $0.1 \mathrm{ml}$ olive oil or double distilled water (DDW), respectively. Olive oil was administered to mice in the fifth group as a placebo control.

The 25 mice that were treated with intraperitoneal (IP) injections of TQ were divided equally into five groups. Mice in the first four groups were intraperitoneally inoculated with $B$. microti-infected RBCs as described above, and mice in the fifth group remained without infection and were used as a blank control. Mice in the first and second groups received an intraperitoneal (IP) injection of TQ and subcutaneous (SC) injection of DA at dose rates of 25 and $50 \mathrm{mg} / \mathrm{kg}$, 
respectively [22]. A combination of TQ (IP injection) and DA (SC injection) was administrated to mice in the third group at dose rates of 25 and $10 \mathrm{mg} / \mathrm{kg}$, respectively, in the same inoculation period. Olive oil $(0.1 \mathrm{ml})$ was administrated intraperitoneally to mice in the fourth group, and served as a positive control [22]. For all treated mice, the specific drug or solvent was administrated for 5 successive days when parasitemia reached $1 \%$ in the infected mice. Venous tail blood samples (2.5 $\mu \mathrm{l})$ were collected from each mouse every 2 days until 20 days post-inoculation or the cessation of parasitemia. Non-parasitized RBCs from uninfected mice were used as a blank control. The blood samples were collected in a 96-well plate containing RPMI 1640 medium previously mixed with $50 \mu \mathrm{l}$ of a lysis buffer to prevent blood coagulation. After that, $50 \mu \mathrm{l}$ of a lysis buffer containing $2 \times$ SGI nucleic acid stain was added directly to each well and gently mixed. Next the plate was incubated in the dark for $1 \mathrm{~h}$ and the fluorescence values determined as described above using a fluorescence spectrophotometer.

\section{Role of TQ in treatment of anemia associated with Babesia}

Venous tail blood samples $(10 \mu \mathrm{l})$ were collected from all treated mice, and hematological variables including hematocrit (HCT) values, hemoglobin (HGB) levels, red blood cell (RBC) counts, mean corpuscular volume $(\mathrm{MCV})$, mean corpuscular hemoglobin $(\mathrm{MCH})$ and $\mathrm{RBC}$ distribution width (RDW) were measured and used as indicators of the anemia development in these mice. Mice that did not receive any infection or drug treatment served as a negative control. In all groups, the hematological parameters were monitored every $96 \mathrm{~h}$ using the Celltac $\alpha$ MEK-6450 automatic hematology analyzer (Nihon Kohden Corporation, Tokyo, Japan).

\section{Statistical analysis}

The significant differences between groups were determined by independent Student's t-test and one-way ANOVA test using GraphPad Prism version 5.0 for Windows (GraphPad Software Inc., San Diego, CA, USA). A $P$-value of $<0.05$ was considered statistically significant. The regrowth of the parasite in the viability test was determined based on the statistically significant differences between drug-treated and positive control groups [7].

\section{Results}

\section{In vitro inhibitory effect and drug combination test}

The in vitro growth of $B$. bovis was significantly inhibited (t-test: $t_{(4)}=6.02, P=0.003$ ) by a $0.25 \mu \mathrm{M}$ treatment of TQ. The in vitro growth of the other Babesia and Theileria parasites tested was significantly inhibited (t-test: $t_{(4)}=12.01, P=0.0003$ for $B$. bigemina; $t_{(4)}=$
54.46, $P<0.0001$ for $B$. divergens; $t_{(4)}=6.47, P=0.002$ for T. equi; and $t_{(4)}=19.77, P<0.0001$ for $B$. caballi) by a $0.01 \mu \mathrm{M}$ treatment of TQ (Additional file 1: Figure S1). Babesia divergens and B. bigemina were the most susceptible parasites to the in vitro inhibition effect of TQ, followed by B. bovis (Table 1). In contrast, equine Babesia and Theileria parasites exhibited in vitro resistance to the TQ inhibitory effect (Table 1). Consequently, the ability of TQ to inhibit the regrowth of Babesia and Theileria parasites after 4 days of in vitro treatment was assessed using a viability test. The results revealed no regrowth of the $B$. bovis, B. bigemina, B. divergens, T. equi or B. caballi parasites at 400,100, 5, 200 or $10 \mu \mathrm{M}$ treatments, respectively. Moreover, a $0.5 \mu \mathrm{M}$ DA treatment was sufficient to suppress the regrowth of Babesia and Theileria parasites.

Notably, combination therapy consisting of $4.44 \mu \mathrm{M}$ TQ $\left(1 / 16 \mathrm{IC}_{50}\right)$ and $0.35 \mu \mathrm{M}$ DA $\left(1 / 2 \mathrm{IC}_{50}\right)$ significantly enhanced the growth inhibition of $T$. equi better than those observed by $\mathrm{DA} \mathrm{IC}_{50}$ (Table 2). Furthermore, 1.00 $\mu \mathrm{M}$ TQ $\left(1 / 16 \mathrm{IC}_{50}\right)$ and $0.10 \mu \mathrm{M}$ DA $\left(1 / 2 \mathrm{IC}_{50}\right), 0.14 \mu \mathrm{M}$ TQ $\left(1 / 16 \mathrm{IC}_{50}\right)$ and $0.10 \mu \mathrm{M}$ DA $\left(1 / 2 \mathrm{IC}_{50}\right)$, and 9.38 $\mu \mathrm{M}$ TQ $\left(\begin{array}{lllll}1 / 16 & \left.\mathrm{IC}_{50}\right)\end{array}\right)$ and $0.0035 \mu \mathrm{MA}\left(1 / 2 \quad \mathrm{IC}_{50}\right)$ significantly enhanced the inhibitory effect of TQ on $B$. bovis (Table 3), B. bigemina (Table 4) and B. caballi (Table 5), respectively, in in vitro cultures. Moreover, treatments of B. bovis, B. bigemina and B. caballi parasites with TQ and DA combination therapy enhanced their growth inhibition significantly better than those observed by DA $\mathrm{IC}_{50}$ for $B$. bovis $\left(8.87 \mu \mathrm{M}\right.$ TQ $\left(1 / 4 \mathrm{IC}_{50}\right): 0.30 \mu \mathrm{M}$ DA (3/4 IC $\left.\mathrm{IC}_{50}\right)$ (Table 3), B. bigemina $(1.83 \mu \mathrm{M}$ TQ $(1 / 4$ $\left.\mathrm{IC}_{50}\right): 0.10 \mu \mathrm{M}$ DA $\left(1 / 2 \mathrm{IC}_{50}\right)$ (Table 4$)$ and B. caballi ( $9.38 \mu \mathrm{M}$ TQ $\left(1 / 16 \quad \mathrm{IC}_{50}\right): 0.0052 \mu \mathrm{M}$ DA $\left(3 / 4 \quad \mathrm{IC}_{50}\right)$ (Table 5). These results confirmed the potential antibabesial effect of TQ, especially when administrated simultaneously with DA.

Table $1 I_{50}$ values of thymoquinone and diminazene aceturate evaluated for bovine Babesia and equine Babesia and Theileria parasites

\begin{tabular}{lll}
\hline Organism & \multicolumn{1}{l}{$\mathrm{C}_{50}(\mu \mathrm{M})^{\mathrm{a}}$} \\
\cline { 2 - 3 } & Thymoquinone & Diminazene aceturate \\
\hline B. bovis & $35.41 \pm 3.60$ & $0.415 \pm 0.07$ \\
B. bigemina & $7.35 \pm 0.17$ & $0.209 \pm 0.005$ \\
B. divergens & $0.28 \pm 0.016$ & $0.12 \pm 0.03$ \\
T. equi & $74.05 \pm 4.55$ & $0.709 \pm 0.047$ \\
B. caballi & $67.33 \pm 0.94$ & $0.007 \pm 0.0002$ \\
\hline
\end{tabular}

${ }^{a} \mathrm{IC}_{50}$ values for thymoquinone and diminazene aceturate were calculated on the fourth day based on the growth inhibitions determined using a fluorescencebased assay in three separate experiments. Each drug concentration was made in triplicate in each experiment, and the final obtained $I_{50}$ represents the mean and standard deviation of three separate experiments 
Table 2 Concentrations and growth inhibition effect of thymoquinone combined with diminazene aceturate applied to the cultures of $T$. equi

\begin{tabular}{|c|c|c|c|c|c|c|}
\hline \multirow{2}{*}{\multicolumn{2}{|c|}{$\begin{array}{l}\text { Concentration } \\
(\mu \mathrm{M})^{\mathrm{a}}\end{array}$}} & \multirow{3}{*}{$\begin{array}{l}\text { Fluorescence } \\
\text { value }^{\mathrm{b}}\end{array}$} & \multicolumn{4}{|l|}{ t-test $^{c}$} \\
\hline & & & \multicolumn{2}{|l|}{$t$-value } & \multicolumn{2}{|l|}{$P$-value } \\
\hline TQ & DA & & Control & $D A I C_{50}$ & Control & $\mathrm{DA} I \mathrm{C}_{50}$ \\
\hline 55.50 & 0.52 & $8.22 \pm 0.51$ & 51.44 & 374.20 & $<0.0001$ & $<0.0001$ \\
\hline 55.50 & 0.35 & $9.67 \pm 0.12$ & 51.25 & 819.37 & $<0.0001$ & $<0.0001$ \\
\hline $37: 00$ & 0.52 & $11.75 \pm 0.77$ & 50.73 & 251.90 & $<0.0001$ & $<0.0001$ \\
\hline $37: 00$ & 0.35 & $11.32 \pm 0.47$ & 50.91 & 390.17 & $<0.0001$ & $<0.0001$ \\
\hline 18.50 & 0.52 & $14.68 \pm 0.42$ & 50.33 & 414.77 & $<0.0001$ & $<0.0001$ \\
\hline 18.50 & 0.35 & $16.31 \pm 0.26$ & 50.07 & 569.11 & $<0.0001$ & $<0.0001$ \\
\hline 4.44 & 0.52 & $17.09 \pm 0.14$ & 49.94 & 738.13 & $<0.0001$ & $<0.0001$ \\
\hline 4.44 & 0.35 & $19.21 \pm 0.79$ & 49.41 & 230.24 & $<0.0001$ & $<0.0001$ \\
\hline \multicolumn{2}{|c|}{ Control } & $299.71 \pm 9.80$ & & & & \\
\hline \multicolumn{2}{|c|}{$\mathrm{DA} I \mathrm{C}_{50}$} & $128.22 \pm 0.22$ & & & & \\
\hline
\end{tabular}

${ }^{\mathrm{a}}$ Combinations were based on the calculated $\mathrm{IC}_{50}$ values obtained from the in vitro Babesia fluorescence assay

${ }^{b}$ Each value was calculated using a fluorescence-based assay in three separate experiments. Each concentration of the drug combination was made in triplicate in each experiment, and the final obtained fluorescence values represent the mean and standard deviation (SD) of three separate experiments after subtracting the background fluorescence for non-parasitized RBCs

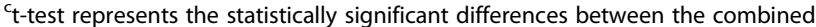
drug-treated group and either the control group or the diminazene aceturate-treated group

Abbreviations: $T Q$ thymoquinone, $D A$ diminazene aceturate

Table 3 Concentrations and growth inhibition effect of thymoquinone combined with diminazene aceturate applied to the cultures of $B$. bovis

\begin{tabular}{|c|c|c|c|c|c|c|}
\hline \multirow{2}{*}{\multicolumn{2}{|c|}{$\begin{array}{l}\text { Concentration } \\
(\mu \mathrm{M})^{\mathrm{a}}\end{array}$}} & \multirow{3}{*}{$\begin{array}{l}\text { Fluorescence } \\
\text { value }^{b}\end{array}$} & \multicolumn{4}{|l|}{ t-test ${ }^{c}$} \\
\hline & & & \multicolumn{2}{|l|}{$t$-value } & \multicolumn{2}{|l|}{$P$-value } \\
\hline TQ & DA & & Control & $\mathrm{DA} I \mathrm{C}_{50}$ & Control & $D A I C_{50}$ \\
\hline 26.62 & 0.30 & $13.79 \pm 0.56$ & 78.53 & 256.26 & $<0.0001$ & $<0.0001$ \\
\hline 26.62 & 0.10 & $20.13 \pm 0.58$ & 76.42 & 235.60 & $<0.0001$ & $<0.0001$ \\
\hline 17.75 & 0.30 & $87.01 \pm 0.20$ & 54.74 & 115.21 & $<0.0001$ & $<0.0001$ \\
\hline 17.75 & 0.10 & $90.42 \pm 0.51$ & 53.40 & 73.90 & $<0.0001$ & $<0.0001$ \\
\hline 8.87 & 0.30 & $111.99 \pm 1.54$ & 44.63 & 7.75 & $<0.0001$ & 0.0015 \\
\hline 8.87 & 0.10 & $163.91 \pm 3.11$ & 25.24 & 24.67 & $<0.0001$ & $<0.0001$ \\
\hline 1.00 & 0.30 & $175.62 \pm 1.88$ & 23.99 & 50.64 & $<0.0001$ & $<0.0001$ \\
\hline 1.00 & 0.10 & $183.29 \pm 2.68$ & 20.43 & 40.89 & $<0.0001$ & $<0.0001$ \\
\hline \multicolumn{2}{|c|}{ Control } & $252.74 \pm 5.24$ & & & & \\
\hline \multicolumn{2}{|c|}{$\mathrm{DA} I \mathrm{C}_{50}$} & $119.16 \pm 0.44$ & & & & \\
\hline
\end{tabular}

${ }^{\mathrm{a}}$ Combinations were based on the calculated $I C_{50}$ values obtained from the in vitro Babesia fluorescence assay

${ }^{\mathrm{b}}$ Each value was calculated using a fluorescence-based assay in three separate experiments. Each concentration of the drug combination was made in triplicate in each experiment, and the final obtained fluorescence values represent the mean and standard deviation (SD) of three separate experiments after subtracting the background fluorescence for non-parasitized RBCs

${ } \mathrm{t}$-test represents the statistically significant differences between the combined drug-treated group and either the control group or the diminazene aceturate-treated group

Abbreviations: $T Q$ thymoquinone, $D A$ diminazene aceturate
Table 4 Concentrations and growth inhibition effect of thymoquinone combined with diminazene aceturate applied to the cultures of B. bigemina

\begin{tabular}{|c|c|c|c|c|c|c|}
\hline \multirow{2}{*}{\multicolumn{2}{|c|}{$\begin{array}{l}\text { Concentration } \\
(\mu \mathrm{M})^{\mathrm{a}}\end{array}$}} & \multirow{3}{*}{$\begin{array}{l}\text { Fluorescence } \\
\text { value }^{\mathrm{b}}\end{array}$} & \multicolumn{4}{|l|}{ t-test ${ }^{c}$} \\
\hline & & & \multicolumn{2}{|l|}{$t$-value } & \multicolumn{2}{|l|}{$P$-value } \\
\hline TQ & DA & & Control & $\mathrm{DA} I \mathrm{C}_{50}$ & Control & $\mathrm{DA} I C_{50}$ \\
\hline 5.51 & 0.15 & $8.81 \pm 1.03$ & 287.14 & 59.50 & $<0.0001$ & $<0.0001$ \\
\hline 5.51 & 0.10 & $9.13 \pm 1.60$ & 213.64 & 54.50 & $<0.0001$ & $<0.0001$ \\
\hline 3.67 & 0.15 & $11.40 \pm 0.97$ & 293.43 & 58.36 & $<0.0001$ & $<0.0001$ \\
\hline 3.67 & 0.10 & $12.09 \pm 2.20$ & 162.84 & 47.52 & $<0.0001$ & $<0.0001$ \\
\hline 1.83 & 0.15 & $26.17 \pm 2.88$ & 120.20 & 35.62 & $<0.0001$ & $<0.0001$ \\
\hline 1.83 & 0.10 & $33.46 \pm 0.86$ & 281.21 & 45.44 & $<0.0001$ & $<0.0001$ \\
\hline 0.14 & 0.15 & $207.37 \pm 1.54$ & 27.38 & 56.66 & $<0.0001$ & $<0.0001$ \\
\hline 0.14 & 0.10 & $223.99 \pm 2.27$ & 8.21 & 58.04 & 0.0012 & $<0.0001$ \\
\hline \multicolumn{2}{|c|}{ Control } & \multicolumn{5}{|l|}{$235.57 \pm 0.90$} \\
\hline \multicolumn{2}{|c|}{$\mathrm{DA} I \mathrm{C}_{50}$} & \multicolumn{5}{|l|}{$106.81 \pm 2.66$} \\
\hline
\end{tabular}

${ }^{a}$ Combinations were based on the calculated $I C_{50}$ values obtained from the in vitro Babesia fluorescence assay

${ }^{b}$ Each value was calculated using a fluorescence-based assay in three separate experiments. Each concentration of the drug combination was made in triplicate in each experiment, and the final obtained fluorescence values represent the mean and standard deviation (SD) of three separate experiments after subtracting the background fluorescence for non-parasitized RBCs

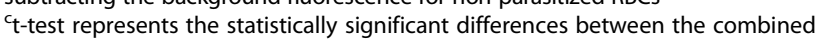
drug-treated group and either the control group or the diminazene aceturate-treated group

Abbreviations: $T Q$ thymoquinone, $D A$ diminazene aceturate

Table 5 Concentrations and growth inhibition effect of thymoquinone combined with diminazene aceturate applied to the cultures of $B$. caballi

\begin{tabular}{|c|c|c|c|c|c|c|}
\hline \multirow{2}{*}{\multicolumn{2}{|c|}{$\begin{array}{l}\text { Concentration } \\
(\mu \mathrm{M})^{\mathrm{a}}\end{array}$}} & \multirow{3}{*}{$\begin{array}{l}\text { Fluorescence } \\
\text { value }^{b}\end{array}$} & \multicolumn{4}{|l|}{ t-test $^{c}$} \\
\hline & & & \multicolumn{2}{|l|}{ t-value } & \multicolumn{2}{|l|}{$P$-value } \\
\hline $\mathrm{TQ}$ & DA & & Control & $\mathrm{DA} I \mathrm{C}_{50}$ & Control & $\mathrm{DA} I C_{50}$ \\
\hline 50.25 & 0.0052 & $79.25 \pm 0.47$ & 450.67 & 156.58 & $<0.0001$ & $<0.0001$ \\
\hline 50.25 & 0.0035 & $92.75 \pm 1.45$ & 216.27 & 54.18 & $<0.0001$ & $<0.0001$ \\
\hline 33.50 & 0.0052 & $104.32 \pm 1.02$ & 266.65 & 55.57 & $<0.0001$ & $<0.0001$ \\
\hline 33.50 & 0.0035 & $113.25 \pm 1.70$ & 169.62 & 26.80 & $<0.0001$ & $<0.0001$ \\
\hline 16.75 & 0.0052 & $115.22 \pm 0.83$ & 287.37 & 45.66 & $<0.0001$ & $<0.0001$ \\
\hline 16.75 & 0.0035 & $121.89 \pm 0.71$ & 302.17 & 37.62 & $<0.0001$ & $<0.0001$ \\
\hline 9.38 & 0.0052 & $125.12 \pm 0.85$ & 267.38 & 27.38 & $<0.0001$ & $<0.0001$ \\
\hline 9.38 & 0.0035 & $162.39 \pm 2.60$ & 83.74 & 14.24 & $<0.0001$ & 0.0001 \\
\hline \multicolumn{2}{|c|}{ Control } & $292.20 \pm 0.67$ & & & & \\
\hline \multicolumn{2}{|c|}{$\mathrm{DA} \mid \mathrm{C}_{50}$} & $140.63 \pm 0.49$ & & & & \\
\hline
\end{tabular}

${ }^{\mathrm{a} C o m b i n a t i o n s}$ were based on the calculated $I C_{50}$ values obtained from the in vitro Babesia fluorescence assay

${ }^{\mathrm{b}}$ Each value was calculated using a fluorescence-based assay in three separate experiments. Each concentration of the drug combination was made in triplicate in each experiment, and the final obtained fluorescence values represent the mean and standard deviation (SD) of three separate experiments after subtracting the background fluorescence for non-parasitized RBCs

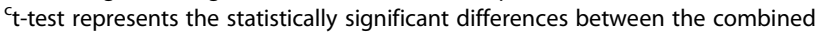
drug-treated group and either the control group or the diminazene aceturate-treated group

Abbreviations: $T Q$ thymoquinone, $D A$ diminazene aceturate 
In vivo effect of TQ on B. microti infection

In the present study, TQ was administered via two routes: oral and intraperitoneal. In mice that received oral TQ treatment, fluorescence values were significantly inhibited (ANOVA: $\left.F_{(1.442,14.42)}=8.84, P=0.005\right)$ in the group treated with either TQ alone at a dose rate of 100 $\mathrm{mg} / \mathrm{kg}$ or TQ in combination with DA from days 4 to 14 post-inoculation (pi) as compared to control mice (Fig. 1a). Treatment with TQ at a dose rate of $70 \mathrm{mg} / \mathrm{kg}$ resulted in significant inhibition of fluorescence values (ANOVA: $\left.F_{(1.442,14.42)}=8.84, P=0.005\right)$ from day 4 to $8 \mathrm{pi}$ as compared to control mice. Control mice treated with olive oil and mice treated with DA alone showed peak fluorescence signals at 6 days pi. Mice treated with TQ alone or in combination with DA showed peak fluorescence signals at 8 days pi, indicating the potential effect of TQ in hindering parasitemia development (Fig. 1a). Notably, mice treated with a combined therapy exhibited inhibition in the fluorescence values, similar to those obtained from mice treated with $25 \mathrm{mg} / \mathrm{kg}$ DA (Fig. 1a). Oral administration of $100 \mathrm{mg} / \mathrm{kg}$ TQ caused 61 and 32\% inhibition rates in the parasite growth at 6 and 8 days pi, respectively. Furthermore, the inhibition rates observed with 70 $\mathrm{mg} / \mathrm{kg}$ oral doses of TQ were $45 \%$ at 6 days pi and $11 \%$ at 8 days pi (Fig. 1a). A $50 \mathrm{mg} / \mathrm{kg}$ oral dose of TQ combined with $10 \mathrm{mg} / \mathrm{kg}$ DA resulted in a $76 \%$ inhibition of B. microti growth at day 6 pi compared with $72 \%$ inhibition in the presence of $25 \mathrm{mg} / \mathrm{kg}$ DA at day 6 pi (Fig. 1a). However, at day 8 pi, TQ/DA

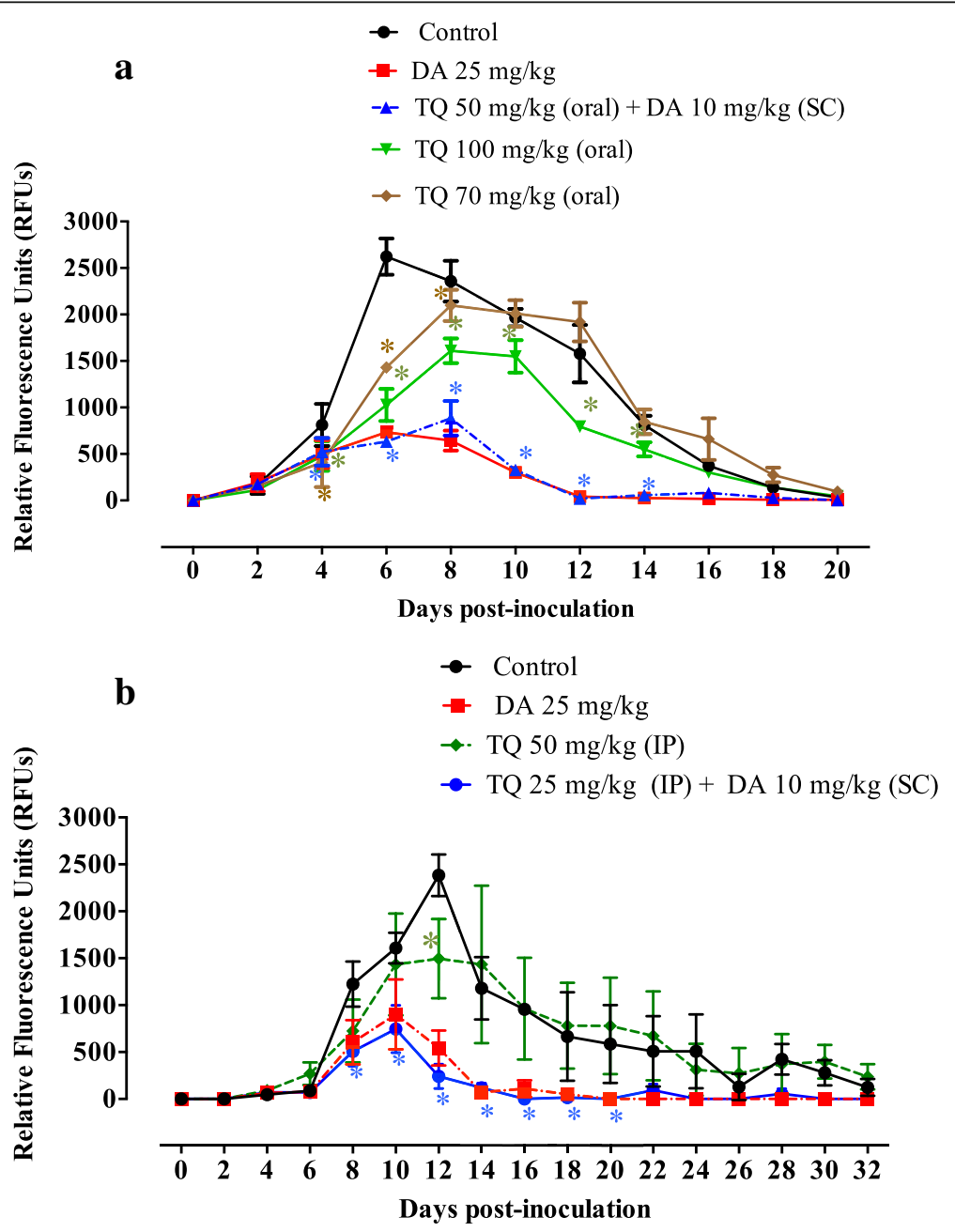

Fig. 1 Inhibitory effect of diminazene aceturate, thymoquinone, and a combination therapy of both drugs on the growth of Babesia microti. a Oral administration of TQ. $\mathbf{b}$ Intraperitoneal administration of TQ. Each value represents the mean \pm standard deviation of five mice per experimental group after subtracting the background fluorescence for non-parasitized RBCs from uninfected mice. Asterisks indicate significant differences $(P<0.05)$ between treated and control mice. Gain values are set to 100. Abbreviations: TQ, thymoquinone; DA, diminazene aceturate; SC, subcutaneous administration; IP, intraperitoneal administration 
combination therapy caused a $62.5 \%$ inhibition rate in parasite growth, and $25 \mathrm{mg} / \mathrm{kg}$ DA resulted in a $72.5 \%$ inhibition rate (Fig. 1a).

For the mice receiving IP treatment with $\mathrm{TQ}$, the fluorescence values were significantly inhibited (ANOVA: $\left.F_{(1.342,21.48)}=17.33, P=0.0002\right)$ in mice treated with a TQ/DA combination from days 8 to $20 \mathrm{pi}$ as compared to those in the control mice (Fig. 1b). Treatment with TQ at a dose rate of $50 \mathrm{mg} / \mathrm{kg}$ resulted in significant inhibition of fluorescence values (ANOVA: $\left.F_{(1.342,21.48)}=17.33, P=0.0002\right)$ at day $12 \mathrm{pi}$ as compared to the control mice (Fig. 1b). Intraperitoneal treatment of B. microti-infected mice with $50 \mathrm{mg} / \mathrm{kg}$ TQ produced a $37 \%$ inhibition rate in parasite growth at 12 days pi (Fig. 1b). Control mice treated with olive oil and mice treated with TQ alone showed peak fluorescence signals at day $12 \mathrm{pi}$, while mice treated with $\mathrm{TQ} / \mathrm{DA}$ combination therapy showed peak fluorescence signals at day 10 pi (Fig. 1b). Noticeably, mice IP injections from the TQ/DA combination formula exhibited fluorescence values lower than those obtained from mice treated with $25 \mathrm{mg} / \mathrm{kg}$ DA alone on the days of peak parasitemia (Fig. 1b). Intraperitoneal administration of TQ in combination with a subcutaneous dose of DA resulted in 54 and $90 \%$ inhibition rates of $B$. microti growth at 10 and 12 days pi, respectively (Fig. 1b). Interestingly, the inhibition rates caused by this combination therapy were higher than the 44 and $77 \%$ inhibition rates caused by DA alone at a dose rate of $25 \mathrm{mg} / \mathrm{kg}$ at days 10 and 12, respectively (Fig. 1b). Collectively, these results reveal that the TQ/DA combination seems to be more effective than treatment with TQ alone and highlights the fact that a combination formula of TQ and DA may be a promising treatment for babesiosis under field conditions.

\section{Role of TQ in retreating of anemia}

The role of TQ in mouse recovery from anemia was evaluated by monitoring the changes in hematological variables. For mice receiving an oral dose of TQ, a significant reduction (ANOVA: $F_{(2.143,8.572)}=5.15, P=$ $0.03)$ in RBC count was observed in B. microti-infected mice treated with olive oil (positive control, PC) and TQ alone on days 4,8 and 12 pi compared to uninfected mice (Fig. 2a). Additionally, a significant reduction (ANOVA: $\left.F_{(2.143,8.572)}=5.15, P=0.03\right)$ in RBC count was observed in mice treated with TQ combined with DA compared to uninfected mice at 8 days pi (Fig. 2a). A significant reduction $\left(\right.$ ANOVA: $F_{(2.295,9.178)}=6.47, P=$ 0.01 ) in HGB level was observed in mice treated with olive oil alone (PC) at 4, 8 and 12 days pi (Additional file 2: Figure S2a). In the same way, such a reduction was perceived in groups treated with TQ alone at days 12 and 16 pi. Unfortunately, mice receiving an oral dose of
TQ alone or olive oil showed a significant reduction (ANOVA: $\left.F_{(1.484,5.936)}=8.90, P=0.01\right)$ in HCT levels until day 20 pi (Additional file 2: Figure S2b). Surprisingly, no such reduction was observed in HGB and HCT levels in mice treated with TQ combined with DA (Additional file 2: Figure S2a, b). Macrocytic anemia and anisocytosis were observed in all treated mice from day 8 pi, while from day $12 \mathrm{pi}$, combination therapy with TQ and DA had the ability to eliminate this anemia and yield a uniform population of red blood cells (Additional file 2: Figure S2c, e). Subsequently, a significant increase (ANOVA: $F_{(1.734,6.935)}=5.64, P=0.03$ ) in the $\mathrm{MCH}$ level was observed in mice that received oral doses of TQ or olive oil alone from day 8 pi (Additional file 2: Figure S2d).

Notably, intraperitoneal administration of TQ at 25 $\mathrm{mg} / \mathrm{kg}$ in combination with $10 \mathrm{mg} / \mathrm{kg}$ DA was sufficient to normalize the RBC count (Fig. 2a), HGB level and HCT percentage at day $12 \mathrm{pi}$ in treated mice (Additional file 3: Figure S3a, b). In contrast, the significant reduction in RBC count (ANOVA: $F_{(2.817,16.90)}=25.87, P<$ $0.0001)$, HGB level (ANOVA: $F_{(3.098,18.59)}=9.35, P=$ $0.0005)$ and HCT percentage (ANOVA: $F_{(2.661,15.97)}=$ 12.90, $P=0.0002$ ) was still detected in $B$. microti-infected mice treated with intraperitoneal doses of TQ alone $(50 \mathrm{mg} / \mathrm{kg})$ on days 20,12 and $12 \mathrm{pi}$, respectively (Fig. 2a and Additional file 3: Figure S3a, b). All treated mice exhibited a significant elevation in MCV (ANOVA: $\left.F_{(2.068,12.41)}=19.01, P=0.0002\right)$ and RDW (ANOVA: $\left.F_{(1.312,7.874)}=7.21, P=0.0231\right)$ levels at day $12 \mathrm{pi}$, indicating the presence of macrocytic anemia and anisocytosis (Additional file 3: Figure S3c, e). Subsequently, a significant increase (ANOVA: $F_{(2.203,13.22)}=10.56, P=$ $0.0015)$ in the $\mathrm{MCH}$ level was observed in mice that received intraperitoneal doses of TQ $(50 \mathrm{mg} / \mathrm{kg})$ or olive oil alone from day 12 pi (Additional file 3: Figure S3d). Interestingly, at day $16 \mathrm{pi}$, this anemia and disturbances in the RBC population disappeared in mice treated with intraperitoneal doses of DA $(25 \mathrm{mg} / \mathrm{kg})$ alone or DA (10 $\mathrm{mg} / \mathrm{kg}$ ) in combination with TQ $(25 \mathrm{mg} / \mathrm{kg}$ ) (Additional file 3: Figure S3c). These findings highlight the efficacy of low oral or intraperitoneal doses of TQ and DA in combination with a fast recovery from anemia and anisocytosis in treated mice and indicate the potential antibabesial effect of this combination therapy.

\section{Discussion}

Thymoquinone is an ancient phytochemical compound and its wide pharmacological activity as a hepatoprotective, cardioprotective, anti-inflammatory, anti-convulsant, anti-microbial, anti-histaminic and anti-diabetic has been evidently proved [23, 24]. Additionally, the therapeutic effect of TQ in treating many clinical disorders such as acute gastric ulcer, neurodegenerative and neuropsychiatric 


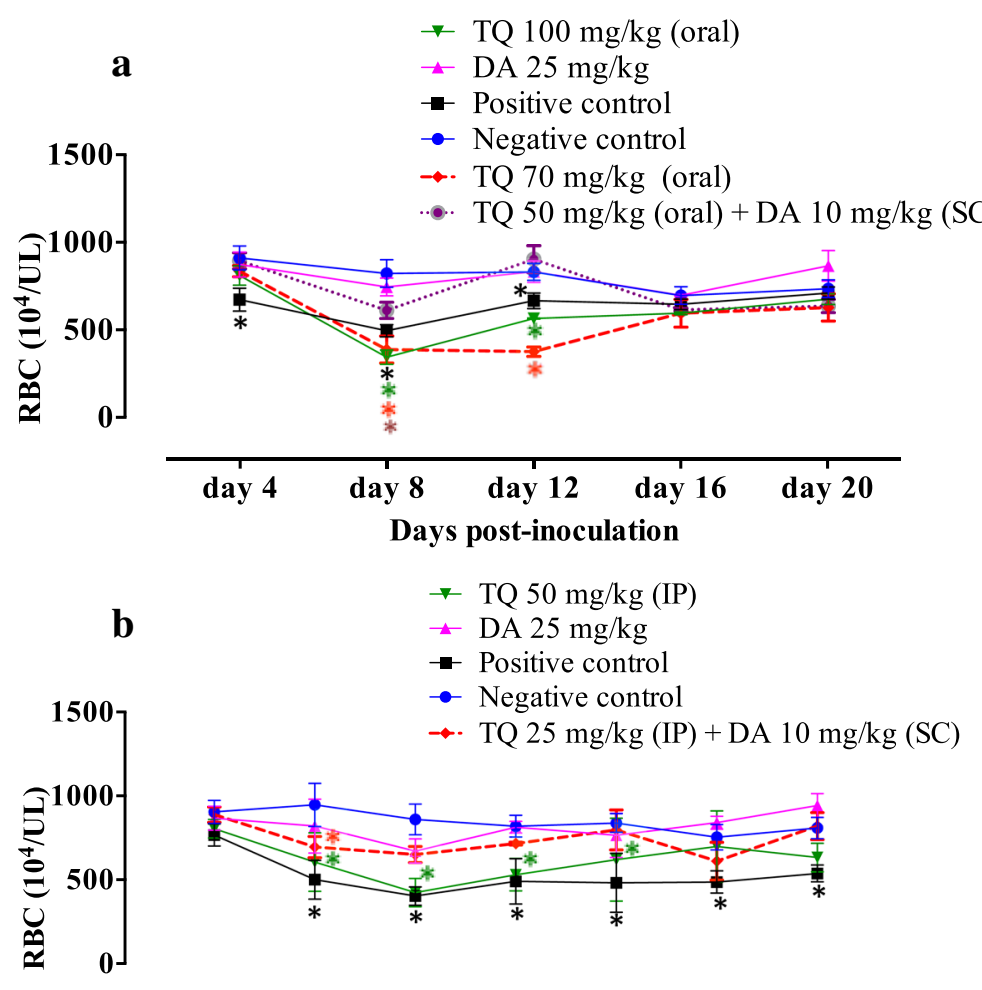

day 4 day 8 day 12 day 16 day 20 day 24 day 28

Days post-inoculation

Fig. 2 RBC counts in mice treated with thymoquinone. a Oral administration of TQ. b Intraperitoneal administration of TQ. Each value represents the mean \pm standard deviation of five mice per experimental group. Asterisks indicate a significant difference $(P<0.05)$ between treated or infected mice and uninfected mice. Abbreviations: TQ, thymoquinone; DA, diminazene aceturate; SC, subcutaneous administration; IP,

intraperitoneal administration

diseases, rheumatoid arthritis, and respiratory disorders including asthma and dyspnea has been reported [24]. In this regard, the antibabesial effect of TQ has been evaluated in the present study.

The $\mathrm{IC}_{50}$ values of $\mathrm{TQ}$ for piroplasma parasites were higher than those of pyronaridine tetraphosphate, luteolin, nimbolide and gedunin [6, 7]; MMV006706, MMV666093, MMV396693, MMV073843 and MMV665875 hits [25]; clofazimine [26]; epoxomicin [5]; ciprofloxacin, thiostrepton, and rifampicin [4]; DA and imidocarb dipropionate (commonly used antibabesial drugs) [20]; enoxacin against B. bovis, T. equi and B. caballi [6]; and fusidic acid and clindamycin phosphate against equine Babesia and Theileria parasites $[27,28]$. On the other hand, the $\mathrm{IC}_{50}$ values of $\mathrm{TQ}$ for piroplasma parasites were lower than those of N-Acetyl-L-cysteine [8], allicin [19], fusidic acid, clodinafop-propargyl, and clindamycin phosphate against bovine Babesia parasites [20, 28]; chloroquine diphosphate and metronidazole against B. gibsoni [27]; and enoxacin against B. bigemina [6]. The viability test results exhibited the ability of TQ to suppress the regrowth of piroplasma parasites at lower concentrations in comparison with the results observed for allicin [19] and N-Acetyl-L-cysteine [8] on B. bigemina, B. divergens, T. equi and B. caballi, and for fusidic acid on B. caballi [28]. The in vitro application of TQ inhibited regrowth of the $B$. bovis parasite at concentrations similar to those observed for $\mathrm{N}$-Acetyl-L-cysteine [8] and fusidic acid [28] on $B$. bovis, B. bigemina and T. equi.

To further validate the antibabesial efficacy of TQ, the in vivo inhibitory effect of TQ was evaluated in B. microti-infected mice in two separate trials. Even the same drug showed different chemotherapeutic effects with different administrative routes [29]. A recent study [26] in our laboratory reported different inhibitory effects of clofazimine on the growth of $B$. microti in mice when administrated in two different routes. Oral administration of the drug showed a much higher effect than the intraperitoneal route. Therefore, in the present study, to evaluate the possible effect of different administration methods of TQ on the growth of the Babesia parasite, TQ was administrated via oral and intraperitoneal routes. Intraperitoneal treatment of B. microti-infected mice with $50 \mathrm{mg} / \mathrm{kg}$ TQ produced a higher inhibition rate $(37 \%)$ than those of (11 and 32\% for 70 and 100 $\mathrm{mg} / \mathrm{kg} \mathrm{TQ}$, respectively) by oral TQ treatment on the 
days of peak parasitemia. Furthermore, the inhibition rates in the fluorescence values obtained from treatment of B. microti-infected mice with TQ/DA combination therapy were higher in mice which received intraperitoneal injections of TQ than in mice treated orally with TQ when compared with the inhibition rates caused by DA alone at a dose rate of $25 \mathrm{mg} / \mathrm{kg}$ on the days of peak parasitemia. Generally speaking, the rate of absorption is the fastest for the intravenous route and then decreases in the following order: intraperitoneal > intramuscular > subcutaneous $>$ oral [30]. Therefore, for the present study, the intraperitoneal administration of TQ seems to be more effective than oral administration for the treatment of Babesia parasites.

The in vivo inhibitory effects of TQ against B. microti when administrated via the oral route are lower than $77.5 \%$ inhibition for $500 \mathrm{mg} / \mathrm{kg}$ thiostrepton, $68.5 \%$ for $500 \mathrm{mg} / \mathrm{kg}$ clindamycin, $84 \%$ for $10 \mathrm{mg} / \mathrm{kg}(-)$-epigallocatechin-3-gallate, $86 \%$ for $2.5 \mathrm{mg} / \mathrm{kg}$ heparin, and $72.4 \%$ for $100 \mathrm{mg} / \mathrm{kg}$ allicin $[18,19,31]$. In contrast, the inhibition rate of $B$. microti in vivo growth caused by a 100 $\mathrm{mg} / \mathrm{kg}$ oral dose of TQ was higher than $53.7 \%$ for 100 $\mathrm{mg} / \mathrm{kg}$ nerolidol, $58.3 \%$ for $30 \mathrm{mg} / \mathrm{kg}$ allicin, and 36.3 and $47.6 \%$ for 0.05 and $0.5 \mathrm{mg} / \mathrm{kg}$ epoxomicin, respectively $[5,19,32]$. Combination therapy of TQ with lower doses of DA was tested in mice infected with $B$. microti. The in vivo inhibitory effects of TQ when administrated via the oral route in combination with a subcutaneous doses of DA against B. microti are lower than 88.3, 87.1, 89.9 and $91.9 \%$ inhibition from $12.5 \mathrm{mg} / \mathrm{kg}$ DA combined with $15 \mathrm{mg} / \mathrm{kg}$ allicin and $6.75 \mathrm{mg} / \mathrm{kg}$ DA combined with 15,30 or $50 \mathrm{mg} / \mathrm{kg}$ allicin, respectively [19]. On the other hand, the inhibition rate caused by oral TQ and DA combination was higher than that caused by clindamycin combined with the natural product quinine, which showed $70 \%$ inhibition of the growth of $B$. microti on day $7 \mathrm{pi}$ [33].

The inhibition rate caused by intraperitoneal treatment of $50 \mathrm{mg} / \mathrm{kg}$ TQ against B. microti-infected mice are lower than $77.5 \%$ inhibition for $500 \mathrm{mg} / \mathrm{kg}$ thiostrepton, $68.5 \%$ for $500 \mathrm{mg} / \mathrm{kg}$ clindamycin, $84 \%$ for $10 \mathrm{mg} /$ $\mathrm{kg}(-)$-epigallocatechin-3-gallate, $86 \%$ for $2.5 \mathrm{mg} / \mathrm{kg}$ heparin, $72.4 \%$ for $100 \mathrm{mg} / \mathrm{kg}$ allicin, $53.7 \%$ for $100 \mathrm{mg} / \mathrm{kg}$ nerolidol, and $58.3 \%$ for $30 \mathrm{mg} / \mathrm{kg}$ allicin, respectively [4, $18,19,31]$. In contrast, the inhibition rate of B. microti in vivo growth caused by a $50 \mathrm{mg} / \mathrm{kg}$ IP dose of TQ was higher than $36.3 \%$ for $0.05 \mathrm{mg} / \mathrm{kg}$ epoxomicin [5].

The inhibition rate of intraperitoneal administration of TQ in combination with a subcutaneous dose of DA against $B$. microti are similar to the 88.3, 87.1, 89.9 and $91.9 \%$ inhibition for $12.5 \mathrm{mg} / \mathrm{kg}$ DA combined with 15 $\mathrm{mg} / \mathrm{kg}$ allicin and $6.75 \mathrm{mg} / \mathrm{kg}$ DA combined with 15,30 or $50 \mathrm{mg} / \mathrm{kg}$ allicin, respectively [19]. In contrast, the inhibition rate caused by the intraperitoneally administered dose of TQ combined with the SC-administered dose of DA was higher than that caused by clindamycin combined with the natural product quinine, which showed a $70 \%$ inhibition of the growth of B. microti on day $7 \mathrm{pi}$ [33].

Interestingly, the mice treated with combination therapy consisting of low oral or intraperitoneal doses of TQ and DA in combination exhibited a quick recovery from anemia and anisocytosis associated with babesiosis. Such findings are similar to those caused by enoxacin combined with DA in B. microti-infected mice [34]. The significant reductions in hematological variables observed in olive oil-treated control mice were similar to those previously detected in eight-week-old BALB/c mice infected with B. microti [26].

The results obtained in the present study and the long history of the successful application of TQ in treating different diseases makes TQ a promising candidate for drug development. However, all of the previous studies were performed in experimental animal models which neglected clinical evaluation of TQ efficacy, either in animal or human subjects. In fact, the clinical trials and pharmaceutical development of any promising drug candidate to formulate it into the conventional dosage forms such as tablet and capsule is necessary for translation the experimental findings into reality. Unfortunately, TQ is a phytochemical which has potent hydrophobicity, lipophilicity and a highly thermolabile nature, thereby hindering pharmaceutical development for use in clinical trials [24]. In this regard, many strategies in the last few years have been developed for the pharmaceutical formulation of TQ in order to improve its bioavailability without compromising efficacy and safety, such as construction of TQ using novel nanoformulations or polymeric micelle [24].

It should be noted that there are some limitations to the present study. Although a TQ and DA combination exhibited a potential antibabesial effect, the reason behind this potential inhibitory effect in mice infected with $B$. microti is not fully understood. Therefore, further studies are required to clarify this relationship. Additional studies are also warranted to analyze the possible synergistic effect of TQ and other recently identified potent antibabesial drugs, such as clofazimine [26] and pyronaridine tetraphosphate, $[6,7]$ when administered in combination with each other. Such analysis will help to determine the most effective composition ratio for treatment of Babesia and Theileria in animals in clinical applications.

\section{Conclusions}

In the present study, the inhibitory effects of TQ were demonstrated against piroplasma parasites in vitro and in vivo. The results revealed that $\mathrm{TQ}$ exhibited the 
highest activity against the in vitro growth of $B$. divergens and B. bigemina. Notably, mice treated with a combined therapy with lower doses of TQ and DA exhibited a significant reduction in fluorescence values similar to those obtained from mice treated with high doses of a commonly used antibabesial drug (DA). These results indicate that TQ might be used for the treatment of animal piroplasmosis under field conditions.

\section{Additional files}

Additional file 1: Figure S1. Correlation between RFUs and the logconcentrations of thymoquinone (nM) on Babesia and Theileria parasites. Each value represents the mean of triplicate experiments after subtracting the background fluorescence for non-parasitized RBCs. Gain values were set to 100. (PDF $98 \mathrm{~kb}$ )

Additional file 2: Figure S2. Anemia monitoring in mice treated with oral doses of thymoquinone. a Hemoglobin (HGB). b Hematocrit (HCT). c Mean corpuscular volume (MCV). d Mean corpuscular hemoglobin (MCH). e Red blood cell distribution width (RDW). Each value represents the mean \pm standard deviation of five mice per experimental group. Asterisks indicate a significant difference $(P<0.05)$ between treated or infected mice and uninfected mice. Abbreviations: TQ, thymoquinone; DA, diminazene aceturate; SC, subcutaneous administration. (PDF $247 \mathrm{~kb}$ )

Additional file 3: Figure S3. Anemia monitoring in mice treated with intraperitoneal doses of thymoquinone. a Hemoglobin (HGB). $\mathbf{b}$ Hematocrit (HCT). c Mean corpuscular volume (MCV). d Mean corpuscular hemoglobin $(\mathrm{MCH})$. e Red blood cell distribution width (RDW). Each value represents the mean \pm standard deviation of five mice per experimental group. Asterisks indicate a significant difference $(P<0.05)$ between treated or infected mice and uninfected mice. Abbreviations: TQ, thymoquinone; DA, diminazene aceturate; SC, subcutaneous administration; IP, intraperitoneal administration. (PDF 265 kb)

\section{Abbreviations}

DA: Diminazene aceturate; HCT: Hematocrit; HGB: Hemoglobin; IP: Intraperitoneal administration; MCH: Mean corpuscular hemoglobin; MCV: Mean corpuscular volume; RBC: Red blood cell; RDW: RBC distribution width; SC: Subcutaneous administration; SGI: SYBR Green I; TQ: Thymoquinone

\section{Acknowledgments}

The authors would like to thank Dr Gantuya Sambuu for her technical assistance.

\section{Funding}

This study was supported financially by the Medicines for Malaria Venture MMV Challenge Grant. Mohamed Abdo Rizk is supported by a research grant fellowship for young scientists from the Japan Society for the Promotion of Science (JSPS) and Technology of Japan (ID no. P18091). The funding bodies had no role in the design of the study and collection, analysis and interpretation of data, or in writing the manuscript.

\section{Availability of data and materials}

The datasets generated and/or analyzed during the present study are available from the corresponding author upon reasonable request.

\section{Authors' contributions}

Conceived and designed the experiments: SAEE, MAR and II. Performed the experiments: SAEE and MAR. Analyzed the data: MAR. Contributed reagents/ materials/analysis tools: MAR, SAEE, NY and II. Wrote the manuscript: MAR, SAEE and II. All authors reviewed the manuscript. All authors read and approved the final manuscript.

\section{Ethics approval and consent to participate}

All experimental protocols in this study were approved by the Animal Care and Use Committee, Obihiro University of Agriculture and Veterinary Medicine (approval no. 27-65).

\section{Consent for publication}

Not applicable.

\section{Competing interests}

The authors declare that they have no competing interests.

\section{Publisher's Note}

Springer Nature remains neutral with regard to jurisdictional claims in published maps and institutional affiliations.

\section{Author details}

${ }^{1}$ National Research Center for Protozoan Diseases, Obihiro University of Agriculture and Veterinary Medicine, Inada-Cho, Obihiro, Hokkaido, Japan. ${ }^{2}$ Department of Biochemistry and Chemistry of Nutrition, Faculty of Veterinary Medicine, Mansoura University, Mansoura 35516, Egypt. ${ }^{3}$ Department of Internal Medicine and Infectious Diseases, Faculty of Veterinary Medicine, Mansoura University, Mansoura 35516, Egypt.

Received: 11 October 2018 Accepted: 7 January 2019

Published online: 16 January 2019

\section{References}

1. Uilenberg G. Babesia - a historical overview. Vet Parasitol. 2006;31:3-10.

2. El-Sayed SAE, Rizk MA, Terkawi MA, Yokoyama N, Igarashi I. Molecular identification and antigenic characterization of Babesia divergens erythrocyte binding protein (BdEBP) as a potential vaccine candidate. Parasitol Int. 2017; 66:721-6.

3. El-Sayed SAES, Rizk MA, Terkawi MA, Mousa A, El Said ESES, Elsayed G, et al. Cocktail of Theileria equi antigens for detecting infection in equines. Asian Pac J Trop Biomed. 2015;5:977-81.

4. AbouLaila M, Munkhjargal T, Sivakumar T, Ueno A, Nakano Y, Yokoyama M, et al. Apicoplast targeting antibacterials inhibit the growth of Babesia parasites. Antimicrob Agents Chemother. 2012;56:3196-206.

5. AbouLaila M, Nakamura K, Govind Y, Yokoyama N, Igarashi I. Evaluation of the in vitro growth inhibitory effect of epoxomicin on Babesia parasites. Vet Parasitol. 2010;167:19-27.

6. Rizk MA, El-Sayed SA, Terkawi MA, Youssef MA, El Said El Sel S, Elsayed G, et al. Optimization of a fluorescence-based assay for large-scale drug screening against Babesia and Theileria parasites. PLoS One. 2015;27: e0125276

7. Rizk MA, El-Sayed SA, AbouLaila M, Tuvshintulga B, Yokoyama N, Igarashi I. Large-scale drug screening against Babesia divergens parasite using a fluorescence-based high-throughput screening assay. Vet Parasitol. 2016; 227:93-7.

8. Rizk MA, El-Sayed SAE, AbouLaila M, Yokoyama N, Igarashi I. Evaluation of the inhibitory effect of $\mathrm{N}$-acetyl-L-cysteine on Babesia and Theileria parasites. Exp Parasitol. 2017;179:43-8.

9. Mosqueda J, Olvera-Ramirez A, Aguilar-Tipacamu G, Canto GJ. Current advances in detection and treatment of babesiosis. Curr Med Chem. 2012; 19:1504-18.

10. Al-Ghamdi MS. The anti-inflammatory, analgesic and antipyretic activity of Nigella sativa. J Ethnopharmacol. 2001;76:45-8.

11. Mahmoud MR, El-Abhar HS, Salh S. The effect of Nigella sativa oil against the liver damage induced by Schistosoma mansoni infection in mice. J Ethnopharmacol. 2002;79:1-11.

12. Burits M, Bucar F. Antioxidant activity of Nigella sativa essential oil. Phytother Res. 2000;14:323-8.

13. Fujisaki R, Kamei K, Yamamura M, Nishiya H, Inouye S, Takahashi M, et al. In vitro and in vivo anti-plasmodial activity of essential oils, including hinokitiol. Southeast Asian J Trop Med Public Health. 2012;43:270.

14. Woo CC, Hsu A, Kumar AP, Sethi G, Tan KHB. Thymoquinone inhibits tumor growth and induces apoptosis in a breast cancer xenograft mouse model: the role of p38 MAPK and ROS. PLoS One. 2013;8:e75356.

15. El-Najjar N, Chatila M, Moukadem H, Vuorela H, Ocker M, Gandesiri M, et al. Reactive oxygen species mediate thymoquinone-induced apoptosis and activate ERK and JNK signaling. Apoptosis. 2010;15:183-95. 
16. Badary OA, Nagi MN, Al-Shabanah OA, Al-Sawaf HA, Al-Sohaibani MO, Al-Bekairi AM. Thymoquinone ameliorates the nephrotoxicity induced by cisplatin in rodents and potentiates its antitumor activity. Can J Physiol Pharmacol. 1997:75:1356-61.

17. Al-Shabanah OA, Badary OA, Nagi MN, Al-Gharably NM, Al-Rikabi AC, Al-Bekairi AM. Thymoquinone protects against doxorubicin-induced cardiotoxicity without compromising its antitumor activity. J Exp Clin Cancer Res. 1998;17:193-8.

18. Bork S, Yokoyama N, Ikehara Y, Kumar S, Sugimoto C, Igarashi I. Growthinhibitory effect of heparin on Babesia parasites. Antimicrob Agents Chemother. 2004:48:236-41.

19. Salama AA, AbouLaila M, Terkawi MA, Mousa A, El-Sify A, Allaam M, et al. Inhibitory effect of allicin on the growth of Babesia and Theileria equi parasites. Parasitol Res. 2014;113:275-83.

20. Bork S, Yokoyama N, Matsuo T, Claveria FG, Fujisaki K, Igarashi I. Clotrimazole, ketoconazole, and clodinafoppropargyl inhibit the in vitro growth of Babesia bigemina and Babesia bovis (Phylum Apicomplexa). Parasitology. 2003;127:311-5.

21. Rizk MA, El-Sayed SAES, AbouLaila M, Eltaysh R, Yokoyama N, Igarashi I. Performance and consistency of a fluorescence-based high-throughput screening assay for use in Babesia drug screening in mice. Sci Rep. 2017;7: 12774.

22. Al-Ali A, Alkhawajah AA, Randhawa MA, Shaikh NA. Oral and intraperitoneal LD50 of thymoquinone, an active principle of Nigella sativa, in mice and rats. J Ayub Med Coll Abbottabad. 2008;20:25-7.

23. Banerjee S, Padhye S, Azmi A, Wang Z, Philip PA, Kucuk O, et al. Review on molecular and therapeutic potential of thymoquinone in cancer. Nutr Cancer. 2010;62:938-46.

24. Goyal SN, Prajapati CP, Gore PR, Patil CR, Mahajan UB, Sharma C, et al. Therapeutic potential and pharmaceutical development of thymoquinone: a multitargeted molecule of natural origin. Front Pharmacol. 2017;8:656.

25. Van Voorhis WC, Adams JH, Adelfio R, Ahyong V, Akabas MH, Alano P, et al. Open source drug discovery with the malaria box compound collection for neglected diseases and beyond. PLoS Pathog. 2016;12:e1005763.

26. Tuvshintulga B, AbouLaila M, Davaasuren B, Ishiyama A, Sivakumar T, Yokoyama N, et al. Clofazimine inhibits the growth of Babesia and Theileria parasites in vitro and in vivo. Antimicrob Agents Chemother. 2016;60: 2739-46.

27. Matsuu $A$, Yamasaki $M$, Xuan $X$, Ikadai $H$, Hikasa $Y$. In vitro evaluation of the growth inhibitory activities of 15 drugs against Babesia gibsoni (Aomori strain). Vet Parasitol. 2008;157:1-8.

28. Salama AA, AbouLaila M, Mousa AA, Nayel MA, El-Sify A, Terkawi MA, et al. Inhibitory effect of fusidic acid on the growth of Babesia and Theileria equi parasites. Vet Parasitol. 2013;191:1-10.

29. Turner PV, Brabb T, Pekow C, Vasbinder MA. Administration of substances to laboratory animals: routes of administration and factors to consider. J Am Assoc Lab Anim Sci. 2011;50:600-13.

30. Wolfensohn SE, Lloyd MH. Aleutian disease in laboratory ferrets. Vet Rec 1994;134:100.

31. AbouLaila M, Yokoyama N, Igarashi I. Inhibitory effects of (-)epigallocatechin-3-gallate from green tea on the growth of Babesia parasites. Parasitology. 2010;137:785-91.

32. AbouLaila M, Sivakumar T, Yokoyama N, Igarashi I. Inhibitory effect of terpene nerolidol on the growth of Babesia parasites. Parasitol Int. 2010;59: 278-82.

33. Marley SE, Eberhard ML, Steurer FJ, Ellis WL, McGreevy PB, Ruebush TK 2nd. Evaluation of selected antiprotozoal drugs in the Babesia microti hamster model. Antimicrob Agents Chemother. 1997;41:91-4.

34. Rizk MA, AbouLaila M, El-Sayed SAE, Guswanto A, Yokoyama N, Igarashi Inhibitory effects of fluoroquinolone antibiotics on Babesia divergens and Babesia microti, blood parasites of veterinary and zoonotic importance. Infect Drug Resist. 2018;11:1605-15.

Ready to submit your research? Choose BMC and benefit from:

- fast, convenient online submission

- thorough peer review by experienced researchers in your field

- rapid publication on acceptance

- support for research data, including large and complex data types

- gold Open Access which fosters wider collaboration and increased citations

- maximum visibility for your research: over $100 \mathrm{M}$ website views per year

At BMC, research is always in progress.

Learn more biomedcentral.com/submissions 